\title{
МЕЖДУНАРОДНАЯ КОНФЕРЕНЦИЯ В ЧЕСТЬ 120-ЛеТИЯ СО ДНЯ РОЖДЕНИЯ ПЕРВОГО ПРЕЗИДЕНТА АКАДЕМИИ НАУК КАЗАХСТАНА К.И. САТПАЕВА
}

\author{
(C) 2019 г. Т.Б. Мамиров, А.Ж. Бермагамбетов
}

11-12 апреля 2019 г. состоялась Международная научно-практическая конференция «Академик К.И. Сатпаев и его вклад в становление и развитие науки и производственных сил Казахстана», посвященная 120-летию со дня рождения первого президента Академии наук Казахстана К.И. Сатпаева. Оганизаторами конференции выступили: Историко-производственный музей имени К.И. Сатпаева ТОО «Корпорация Казахмыс», акимат города Жезказган. Для Улытау-Жезказганского региона имя К.И. Сатпаева имеет особое значение, так как именно с ним связано промышленное освоение этого региона, а также образование городов Жезказган, Сатпаев и шахтерских поселков. В ходе конференции обсуждалось о вкладе К.И. Сатпаева не только в промышленное освоение Улытау-Жезказганского региона, но и в его историкоархеологическое изучение. Завершало конференцию возложение цветов к памятнику академику К.И. Сатпаеву и посадка саженцев.

Ключевые слова: археология, К.И. Сатпаев, Улытау-Жезказганский центр, Академия наук Казахстана, конференция, геология, наследие, наука, металлургия

11-12 апреля 2019 г. Историкопроизводственным

музеем

им. К.И. Сатпаева ТОО «Корпорация Казахмыс» в Жезказгане была проведена Международная научнопрактическая конференция «Академик К.И. Сатпаев и его вклад в становление и развитие науки и производственных сил Казахстана», посвященная 120-летию ученого. Для Улытау-Жезказганского региона имя К.И. Сатпаева имеет особое значение, так как именно с ним связано промышленное освоение этого региона, а также образование городов Жезказган, Сатпаев и шахтерских поселков.
В конференции приняли участие ветераны горнорудной промышленности Большого Жезказгана, почетные жители городов Жезказган и Сатпаев, близкие родственники К.И. Сатпаева и А.Х. Маргулана, археологи из Института археологии им. А.Х. Маргулана, краеведы, преподаватели.

Открыло конференцию пленарное заседание, на котором с приветственным словом выступили заместитель акима города Жезказган А.А. Мухамбедин и представитель руководства ТОО «Корпорации Казахмыс» М. Косыбаев. Они рассказали о роли известного ученого в раз- 
витии Жезказган-Улытауского региона, в становлении промышленности, а также о современном состоянии добычи руды, перспективах и задачах.

Близкая родственница К.И. Сатпаева - К.Б. Баязитова рассказала о жизни Каныша Имантаевича, о его семье, о старших родных, поддерживавших его и повлиявших на становление его как ученого. Ознакомила с неизвестными страницами биографии и наследии К.И. Сатпаева.

Данель Алькеевна Маргулан рассказала о тесном сотрудничестве двух великих ученых, особенно подробно остановилась на вопросе о роли К.И. Сатпаева в жизни А.Х. Маргулана, его поддержке в исследовании Центрального Казахстана.
Почетный житель города Жезказган, кандидат технических наук М.Т. Токтамысов в своем докладе рассказал об участии К.И. Сатпаева в становлении Академии наук КазССР и Института горного дела в ее составе.

В докладе Т.Б. Мамирова «Вклад геологов в исследовании каменного века Жезказган-Улытауского региона» показана роль К.И. Сатпаева в изучении археологических памятников в регионе, говорилось о его поддержке археологических изысканий. Приведены сведения о работах геологов, связанных с обнаружением памятников каменного века, вплоть до специализированных исследований Института геологических наук

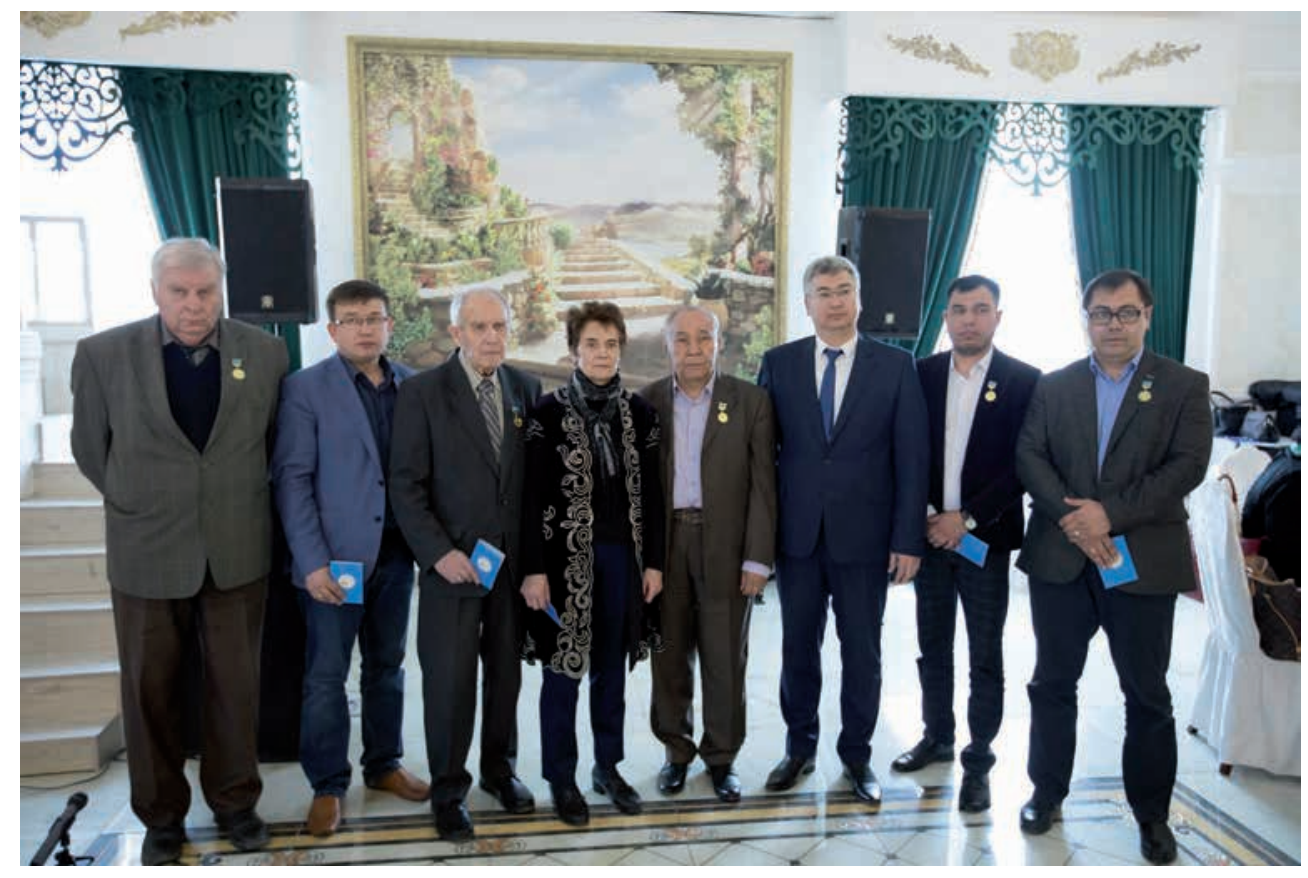

Сотрудники Института археологии им. А.Х. Маргулана среди гостей конференции и руководства «Корпорации Казахмыс». Слева-направо: С.А. Ефименко,

Т.Б. Мамиров, В.П. Прокопьев, А.С. Ермолаева, М.К. Сембин, М.М. Косыбаев, Ж.Р. Утубаев, Д.А. Байтлеу. Фото Е. Мукушева

Staff of A.Kh. Margulan Institute of Archaeology among the guests of the conference and the management of Kazakhmys Corporation. From the left to the right: S.A. Yefimenko,

T.B. Mamirov, V.P. Prokopiev, A.S. Yermolayeva, M.K. Sembin, M.M. Kosybayev, Zh.R. Utubayev, D.A. Baitileu. Photo by Ye. Mukushev 
им. К.И. Сатпаева по изучению четвертичных отложений региона.

Известный обществовед, деятель культуры М.К. Сембин сообщил интересные сведения о роли К.И. Сатпаева в становление топонимики, о том, как он сумел дать казахские местные названия рудникам, месторождениям полезных ископаемых и памятникам, что сыграло большую роль в сохранении исконных казахских топонимов.

Почетный гражданин города Жезказган, председатель «Совета ветеранов» ТОО «Корпорации Казахмыс», Т.Н. Букиров рассказал о наследии К.И. Сатпаева в трудах М. Сарсекеева, С. Букирова. Подробно рассказал о том, как благодаря исследованиям последователей К.И. Сатпаева были открыты многие редкие металлы. Т.Н. Букиров предложил присвоить К.И. Сатпаеву звание «Халық қаһарманы», что было поддержано присутствующими участниками конференции.

Доклад А.С. Ермолаевой был посвящен поселению Талдысай как памятнику древней металлургии Жезказган-Улытауского горно-металлургического центра. В выступлении была показана роль Жезказган-Улытауского центра в Евразии в эпоху бронзового века, рассказано о характере и устройстве металлургических печей, качестве получаемой руды и торговых контактах в древности. Доклад был очень содержательным и вызвал большой интерес среди профессиональных металлургов.

В докладе Д.А. Байтлеу «Вклад К.И. Сатпаева в изучение памятников наскального искусства Центрального Казахстана» была проанализирована еще одна грань деятельности велико- го ученого, внесшего большой вклад в изучение петроглифов Центрального Казахстана. Направления, заданные К.И. Сатпаевым, стали основой для последующих изучений археологических древностей региона.

Доклад Ж.Р. Утубаева был посвящен археологическим исследованиям на памятнике эпохи бронзы Айбас Дарасы в Улытауском регионе, открытом в 1946 году А.Х. Маргуланом и исследованном им в 1972 г. В последующем, благодаря государственному стратегическому проекту «Культурное наследие», на памятнике проводились археологические раскопки сотрудниками Института археологии им. А.Х. Маргулана.

C заключительным докладом выступил старший преподаватель Жезказганского университета имени О.А. Байконурова Г.Ж. Ауезов, который рассказал о выдающихся деятелях Алаш, о роли К.И. Сатпаева в общественно-политической жизни в этот период и о негативных страницах жизни в «сталинское время», о репрессиях, преследовавших семью Сатпаевых.

По окончании пленарного заседания участники научнопрактической конференции приняли резолюцию, где были отмечены следующие основные положения, которые необходимо реализовать: подготовка научной концепции и тематико-экспозицонного плана будущего историко-краевдеческого музея в г. Сатпаев, поиск в архивах г. Москвы документов по истории Карсакпая и Жезказгана, проведение археологических работ на памятнике Милыкудук, озеленение городов и поселков Улытау-Жезказганского региона и издание иллюстрированной книги по результатам празднования 120-летия К.И. Сатпаева. 
Завершала пленарное заседание торжественная часть, в ходе которой было проведено чествование гостей мероприятия памятными нагрудными знаками в честь 120-летия К.И. Сатпаева, подготовленное руководством ТОО «Корпорации Казахмыс».

Культурная часть программы конференции была связана с возложением цветов к памятнику акаде- мику К.И. Сатпаеву в городах Жезказган и Сатпаев, посещение домамузея им. К.И. Сатпаева в поселке Карсакпай, посадка саженцев сирени сорта им. К.И. Сатпаева, посещение Жездинского музея горного и плавильного дела им. М.Торегельдина, а также посадка саженцев сирени сорта им. К.И. Сатпаева на площади горняков в городе Сатпаев.

\section{Сведения об авторах:}

Мамиров Талгат Базарбаевич - кандидат исторических наук, директор, Филиал Института археологии им. А.Х. Маргулана в г. Нур-Султан (г. Нур-Султан, Казахстан); tmamirov@mail.ru

Бермагамбетов Арман Жилкайдарович - главный эксперт, историкопроизводственний музей им. К.И. Сатпаева, ТОО «Корпорация Казахмыс» (г. Жезказган, Казахстан); armankerey@mail.ru

\section{ҚАЗАҚСТАН ҒЫЛЫМ АКАДЕМИЯСЫНЫН ТҰНҒЫШ ПРЕЗИДЕНТІ Қ.И. СӘТБАЕВТЫН ТУЫЛҒАНЫНА 120 ЖЫЛДЫҒЫНА АРНАЛҒАН ХАЛЫҚАРАЛЫҚ КОНФЕРЕНЦИЯ}

\section{Т.Б. Мамиров, А.Ж. Бермағамбетов}

2019 жылдың 11-12 сәуірінде академик Қ.И. Сәтбаевтың 120 жылдығына арналған «Академик Қ.И. Сәтбаев және оның Қазақстан ғылымы мен өндірістік күштерінің қалыптасуы мен дамуына қосқан үлесі» атты Халықаралық ғылымипрактикалық конференция өтті. Конференцияны ұйымдастырушылар: Қ.И. Сәтбаев атындағы тарихи-өндірістік мұражайы, ЖШС «Қазақмыс корпорациясы», Жезқазған қаласының әкімдігі. Ұлытау-Жезқазған өңірі үшін Қаныш Имантайұлы Сәтбаевтың есімі ерекше маңызға ие, өйткені осы өңірді өнеркәсіптік игеру, сондай-ақ Жезқазған, Сәтбаев қалалары мен шахтерлік кенттердің құрылуы онымен байланысты. Конференция барысында Қ.И. Сәтбаевтың Ұлытау-Жезқазған аймағын өнеркәсіптік игеруге ғана емес, сонымен қатар аймақтың тарихи-археологиялық зерттеуіне қосқан үлесі талқыланды. Конференция соңында академик Қ.И. Сәтпаевтың ескерткіштеріне гүл шоқтары қойылып, көшеттер отырғызылып аяқталды.

Түйін сөздер: археология, Қ.И. Сәтбаев Ұлытау-Жезқазған орталығы, Қазақстан Ғылым академиясы, конференция, геология, мұра, ғылым, металлургия

\section{INTERNATIONAL CONFERENCE IN HONOR OF THE 120TH ANNIVERSARY OF K.I. SATPAYEV, THE FIRST PRESIDENT OF THE ACADEMY OF SCIENCES OF KAZAKHSTAN}

\section{T.B. Mamirov, A.Zh. Bermagambetov}

The International Scientific Practical Conference "Academician K.I. Satpayev and his contribution to the formation and development of science and production forces of Kazakhstan" dedicated to the $120^{\text {th }}$ anniversary of the first President of the Academy of 
Мамиров Т.Б., Бермагамбетов А.Ж.Международная конференция в Жезказгане, в честь 120 -летия со дня рождения первого президента Академии наук Казахстана К.И. Сатпаева

Sciences of Kazakhstan was held on 11-12 April 2019. The conference organizers were K.I. Satpayev Historical and Industrial Museum, LLP "Kazakhmys Corporation", Akimat of Zhezkazgan. For Ulytau-Zhezkazgan region, the name Kanysh Imantayevich Satpayev is of particular importance, since industrial development of this region is associated with it, as well as formation of such cities as Zhezkazgan, Satpayev and mining villages. During the conference, K.I. Satpayev's contribution not only in the industrial development of Ulytau-Zhezkazgan region, but also in the historical and archaeological study of the region was discussed. The conference ended with the laying of flowers to the monuments of Academician K.I. Satpayev and planting seedlings.

Keywords: archaeology, K.I. Satpayev, Ulytau-Zhezkazgan center, Academy of Sciences of the Republic of Kazakhstan, conference, geology, heritage, science, metallurgy

\section{About the Authors:}

Mamirov Talgat B. Candidate of Historical Sciences, Director, Branch of the A.Kh. Margulan Archeology Institute in Nur-Sultan, Kazakhstan; tmamirov@mail.ru

Bermagambetov Arman Zh. Chief expert, K.I. Satpayev History and Production Museum, «Kazakhmys Corporation» LLP, Zhezkazgan, Kazakhstan; armankerey@mail.ru

Мақала туралы ақпарат / Информация о статье / Information about the article.

Жариялауға қабылданды / Принята к публикации / Accepted for publication: 08.05.2019. 